\title{
Marketing and social responsibility: an exploratory study of local tourism
}

\author{
Marketing e responsabilidade social: um estudo exploratório do turismo local
}

\author{
Hamilton Pozo
}

Centro Estadual de Educacao Tecnologica Paula Souza, Sao Paulo, Brazil, hprbrazil@hotmail.com

Takeshy Tachizawa

Faculdade Campo Limpo Paulista, Brazil, usptakes@uol.com.br

\begin{abstract}
This study developed a business management model to help stimulate social responsibility innovation and strengthen tourism in the city of Três Corações, Brazil. The research focused on identifying beliefs and values that work together to engender greater engagement and better social performance for companies mainly through innovation in order to strengthen regional tourism. The methodology used was grounded theory, which is a form of qualitative research that seeks to generate new theories through concepts, categories and properties. The proposed model both reflects social responsibility's role in the analysed companies and helps to map the diverse socioeconomic sectors of these companies and the city's tourism industry. The results provide evidence that marketing and social responsibility concerns are increasingly a strategic factor in tourism organisations.
\end{abstract}

Keywords: Social responsibility, social marketing, innovation, tourism.

\section{Resumo}

Este artigo propõe um modelo de gestão para organizações empresariais para ajudar a estimular a inovação em responsabilidade social e fortalecer o turismo na cidade de Três Corações (Brasil). O objetivo deste estudo é apresentar crenças e valores que trabalhem em conjunto para induzir maior engajamento e desempenho social nas empresas em seu campo, particularmente através da inovação para fortalecer o turismo na região estudada. $O$ método de pesquisa utilizado baseou-se na grounded theory que é uma forma de pesquisa qualitativa que busca gerar novas teorias por meio de conceitos, categorias e propriedades. O modelo proposto, além de refletir sobre o papel da responsabilidade social nas empresas analisadas, ajuda a mapear os diversos setores socioeconômicos das empresas pesquisadas e do turismo. $O$ estudo forneceu evidências de que as preocupações com marketing e responsabilidade social estão cada vez mais presentes como um fator estratégico nas organizações.

Palavras-chave: Responsabilidade Social; marketing social, turismo.

According to Srour (2005), capitalist countries and companies navigate with ease through morally ambiguous situations, as self-interest is usually regarded as the engine of the economy. In this context, Scour reanimates the ideas of Weber's ethics when he discusses two alternative approaches: conviction and responsibility. The ethics of belief is interpreted as being based on principles and moral standards and ideals. By discerning the difference between an approach through the ethics of conviction and that of responsibility, it is not difficult to understand why organisations in a market economy are guided by an ethic of responsibility, justifying their actions and the means they use in the name of profits. Currently, given extensive discussions of ethics and behaviour deemed socially responsible, organisations realise that benefits to civil society are associated - with ever-greater clarity - with the quality of goods and services, produced via many intangible elements of these products or services. More recent data on the Brazilian market show that there is a trend towards growth in the social services sector, which is reflected in more marketing and social responsibility programs and the application of their associated tools. This is a paradigm shift that must take place if organisations are genuinely seeking to cultivate corporate social responsibility within their values, culture, mission and vision.

To Kotler (2008), social marketing is a strategy for behaviour change within organisations. Its combination of elements of traditional approaches with social change - within a process that integrates planning and action - takes advantage of 
advances in communications technology and marketing techniques.

\section{Review of the literature}

Corporate social responsibility, in the wake of the disasters that have befallen many organisations, is gaining importance as a management tool to avoid the risks of environmental claims and financial scandals. There was, until recently, the concept that corporate social responsibility was summarised as what companies could offer to their communities through campaigns and community grants. Currently, this concept is evolving and becoming more comprehensive, incorporating other essential factors such as environmental preservation and an appreciation of innovation developers as part of companies, as well as a concern for creating measures that ensure the quality of life within organisations.

Customers in this new business environment expect to interact with organisations that are ethical, have a good corporate image in the market and act in an environmentally responsible manner. In this environment, a concept of social responsibility has emerged that emphasises a commitment to sustainable relationships with stakeholders (e.g. customers, suppliers, internal employees, financial institutions, non-governmental organisations and the general community), as a management tool for the optimisation of economic organisation.

According to Henderson (2006), this perspective has been accentuated in modern settings since the early nineteenth century, as a result of changes occurring in the human values shaped by the Industrial Revolution. These mutations - the essence of human history - have evolved to the present day into social responsibility. This, in turn, can be understood as a form of management that is defined by an ethical and transparent relationship between companies and the general public, as well as the establishment of corporate goals compatible with the sustainable development of society. This also entails preserving environmental and cultural resources, respecting diversity and promoting the reduction of social inequalities (Ethos, 2011; Flammer, 2013; Flammer \& Luo, 2016).

Business involvement in community social action began in the form of voluntary initiatives of companies, such as corporate philanthropy seeking to solve social problems (Craig, 2015, Mitchell, 2012). In the 1960s, the idea spread that companies should take on responsibilities that went beyond their legal obligations regarding social responsibility yet were consistent with their economic activities. One way to contribute to the welfare of society as a whole is through campaigns that aim to achieve a cognitive change in people, helping them to abandon those behaviours or attitudes that are harmful to social life. These campaigns have historically been understood as synonymous with social and community initiatives.

For Carroll, \& Buchholtz (2014) a pyramid of corporate social responsibility values must be acknowledged by the people within businesses who are conscious of social responsibility. This should be framed so that the whole basis of business is regarded as fundamental to social responsibility. This approach suggests that there are four types of social responsibility within corporate social responsibility - economic, legal, ethical and philanthropic - and these can be depicted as a pyramid.

Recent business studies have led to the development of social enterprises associated with the concept of corporate social responsibility, with the basic premise that business and society are interlinked and interdependent. There is thus a set of legitimate expectations of society concerning the work of companies and the results they achieve Burriel (2015 pp.65-74) and Lyons, Hanley, Wearing \& Nei (2012). Later, another component to these proposed results and social impacts of organisational performance, as reflected in observed outcomes associated with companies' relationships with society. In general Schwartz, (2011) model and the later theoretical developments amplify and clarify Carroll's original proposal but do not contradict its premises or its conceptual design (Carroll, 1999). Thus, it can be stated that this interpretation of the social development of companies based on three dimensions remains useful in current research, having survived several rounds of scrutiny by other authors. Similarly, corporate social responsibility can be identified with the principles that guide processes and influence initiatives as implemented in four key commitments that bind companies to society: economic, legal, ethical and philanthropic.

However, after Carroll began to work with Mark Schwartz, he came to believe that the vertical format of his first model does not fully capture the inter-relationship between different levels and can promote the idea that the economic level (which is the base of the pyramid) is more important than the legal level and so on, which is incorrect. Moreover, he now argues that the level of discretion within ethics is unnecessary and cannot be considered the responsibility of businesses since this dimension is already included in ethical guidelines for businesses. Therefore, he has proposed another model that, instead of being pyramidal and having four components, is 'circular' and includes only three components (i.e. economic, legal and ethical), which overlap with each other, with no predominance of one over the other (Carroll \& Schwartz, 2003, pp. 503-530).

In the 1990s, arguments surfaced in favour of viewing social initiatives performed by corporations as not entirely altruistic. At that time, the concept emerged that corporate philanthropy encompasses a variety of activities, among which some may positively affect the profitability of corporations.

Therefore, the idea that the only goal of corporate social responsibility is to generate profits for shareholders has been gradually replaced by the conviction that this responsibility should be considered an investment that can improve organisational performance in the long term. Thus, this research takes as its starting point the idea that a company should be socially responsible and act ethically beyond its legal 
obligations. Given that the current paradigm is based on the simple idea that law enforcement does not equal social responsibility Carroll, \& Buchholtz (2014), we suggest that companies that take legal action to be socially responsible either confuse the two concepts (i.e. law and social responsibility) or seek to add a social emphasis to popular initiatives for purely instrumental purposes.

It is common to confuse the discourses of social responsibility and business ethics, but, in reality, they are two separate areas that share common ground, because corporate social responsibility is a relative concept that depends on the norms, values and social expectations of a given time and place. Therefore, social responsibility is contained within business ethics, as it needs an ethical framework for it to be fully defined (Barakat \& Polo, 2016).

To strengthen the objectives of this research, we chose to adopt a vision in which the concepts of corporate social responsibility and corporate citizenship converge, as suggested by Carroll (1999). A major theoretical criticism made by those who study business and society is the lack of evidence that there is a direct relationship between a socially responsible company and its economic performance, which is needed to support a positive or negative perspective. The arguments in favour of a negative relationship defend the idea that socially responsible companies will be at a competitive disadvantage as a result of incurring higher costs. The proponents of a positive relationship argue that socially irresponsible actions will culminate in an increase in costs, resulting in a competitive disadvantage (Ioannou \& Serafeim, 2014, pp.77-86).

The idea of corporate social responsibility has been recognised, since the 1800s in the United States, in the form of philanthropy and corporate donations, but the current concept was developed only during the 1970 s with the notion that corporations have responsibilities beyond their legal obligations. Corporate social responsibility is analysed following two lines of thought, with the concept of the free market and the socially oriented approach as possible explanations (Burriel, 2015). These last authors cite two definitions of corporate social responsibility: the politics and tactics of social involvement of corporations, beyond legal obligations and for the benefit of society according Enderle \& Tavis (1998, pp. 1129-1143), and the definition in which the purpose of corporate social initiatives is to satisfy social needs (Cox, Burgess, Sellito \& Buultjens, 2009, pp.743-764).

These aspects of philanthropy and proper resource management need to integrate the discourses of business ethics, social marketing and relationship marketing, as well as focusing on the market and the new paradigm of business administration. Another approach is provided by Llena (2007), which features (see Figure 1) the evolution of different concepts of corporate social responsibility, in a comparison of various authors since 1970, with the main features of their approaches.

\begin{tabular}{|c|c|c|c|}
\hline \multicolumn{4}{|c|}{ Figure 1 - Different concepts of corporate social responsibility } \\
\hline TYPES & FEATURES & AUTHORS & LIABILITY \\
\hline $\begin{array}{l}\text { Social } \\
\text { liability }\end{array}$ & $\begin{array}{l}\text { The company } \\
\text { achieves benefits }\end{array}$ & $\begin{array}{l}\text { Caroll, } 1999 \\
\text { King \& Schwartz, } 2000\end{array}$ & Basic \\
\hline $\begin{array}{l}\text { Intermediate } \\
\text { position }\end{array}$ & $\begin{array}{l}\text { Recognises the } \\
\text { existence of some } \\
\text { certain rights social } \\
\text { groups have to satisfy }\end{array}$ & $\begin{array}{l}\text { Watson, } 1972 \\
\text { Drucker, } 1992 \\
\text { Seidel, Whitehead, Mossman \& } \\
\text { Sá, } 2017 \\
\text { Coleman, } 2000\end{array}$ & $\begin{array}{l}\text { Basic } \\
\text { Organisations }\end{array}$ \\
\hline $\begin{array}{l}\text { Company liability } \\
\text { includes the social } \\
\text { aspects }\end{array}$ & $\begin{array}{l}\text { Importance of social } \\
\text { objectives as a whole } \\
\text { or partially }\end{array}$ & $\begin{array}{l}\text { Garcia, } 2001 \\
\text { Caroll \& Schwartz, } 2003 \\
\text { Hiller, } 2013\end{array}$ & $\begin{array}{l}\text { Corporate } \\
\text { Organisations }\end{array}$ \\
\hline
\end{tabular}

Source: Adaptation Llena, 2007.

In this theoretical context, this research project was carried out with local businesses to identify the economic patterns of the region. One of the main hypotheses of this study was to confirm the possibility of social responsibility and social marketing as an alternative in the region's economic development. One of the assumptions adopted in the study was that tourism development generates jobs and income for communities. An additional possibility would be the immediate economic and social development of the city of Três Corações. This economic sector can be a genuine driving force behind economic development in social and cultural regions (Tachizawa, 2011, Racherla \& Hu, 2010, pp. 1012-1034).

Given the region's enormous potential for ecotourism, which is as yet unexplored, this research sought to cover the full range of differentiated services that municipalities have to offer to tourists. The region's tourism potential can be geographic (i.e. already existing naturally), cultural (i.e. created by human activities) and other related aspects (Seade, 2012). Particular emphasis was given to those goods and tourism services that could enable the development of other tourism activities, with the potential for creating jobs and income for local communities.

According to Zenone (2007, pp. 65-67), social marketing is a: [...] marketing extension along substantive dimensions (i.e. the expansion of areas of marketing to focus on the long-term interests of consumers and society). The marketing concept holds that social organisations should determine the needs, desires and interests of target markets and then deliver superior value to customers, to maintain or improve the welfare of clients and society. Marketing management focuses 
on balancing three factors in setting its market policies: corporate profits, consumers' desires and society's interests.

According to Tachizawa, (2011), corporate social marketing includes the activities undertaken by a company in order to obtain the commitment of consumers - with a particular interest in social behaviour - while favouring, at the same time and in a direct manner, the interests of companies and their market position. According to Garcia, Gibaja \& Mujika (2013, pp.61-81), the occasional promotional marketing campaign using tactics to boost sales in the short term should already be the initial phase of corporate social marketing, interpreted as a long-term strategic relationship with some social cause that produces no profit. Thus, companies exercise their social responsibility in harmony with social value, their mission and corporate culture by integrating these with the overall strategies of the companies.

Marketing with a social cause can be considered an alternative form of operational social marketing, with many advantages for companies, both foreign and domestic. For Jones (as cited in Aragon, 2000, p. 46), as a concept, social responsibility refers to the notion that companies have obligations to other constituent groups in society, in addition to shareholders. Chatjuthamard, Jiraporn, Tong' \& Singh, (2015) and Chintrakarn, Jiraporn, Kim \& Kim (2016, pp. 102-123) argues that companies exist to meet goals that are both economic and social. These functions should be performed in an integrated manner. It is clear that the optimisation of profit cannot remain the essential model for entrepreneurial activity. Different audiences of civil society have been influenced in part by mechanisms, the social behaviour of companies and supervisory actions in how they perceive companies' images.

Another level of argument used to justify the adoption of the concept of corporate social responsibility arises from the understanding that the search for sustainable solutions to improve the quality of life and the common good cannot be relegated to the sphere of government, which is often seen as the sole guardian of collective interests. This is the case, especially when considering the weak financial power available to promote these corporate initiatives.

This argument has now been reinforced by the growing process of globalisation and privatisation. In Wu \& Adams's (2007) work, companies face a new challenge: the private sector is forced to occupy more space in the public sector.

Poverty is devastating on the environmental focus, becoming unacceptable from that angle and limiting the social and ethical point of view of the potential market for the productive sector, resulting in limited income, employment and tax generation. Sustainability requires massive integration of millions of people in the market economy each year.

For Gaioto (2001), social responsibility and ethical behaviour include the quality of relationships that companies establish with all their stakeholders. It is a continuous process of learning that must be incorporated into the businesses' management. According to Kotler (2007), marketing is a social and managerial process through which individuals and groups obtain what they need and want through creating, offering and exchanging products of value with others. Many theorists have proposed new approaches to current marketing. Richers (2001), for example, points out some factors behind the emergence of so many different ways to explain marketing, especially those concepts that have nothing to do with businesses or business for profit. This author defines the role of marketing as a key factor in identifying the unmet needs of customers in order to market products or services while meeting the needs of consumers who are not yet satisfied.

Leisinger (2015) has argued that the great challenge of modern marketing is that it can create new brands and brand variants that provide the basis on which consumers can identify and associate with a product or service leader, as well as control their destinies.

Companies must recognise the need to consider all stakeholders when designing and implementing marketing strategies. Micchelli, (2012, pp. 457-475) has suggested that marketing tools interact, producing strong links between organisations and the market to achieve goals and organisational missions. Companies' images play a fundamental role in the purchasing decisions of consumers, involving not only the quality of companies' products and processes but also the effort made concerning social practices (Zenone, 2007, p. 23).

Social marketing as a concept emerged in the United States in 1971, and it was first used by Kotler \& Zaltaman (1971, pp. 3-12), who at the time were studying the application of marketing to contribute to the search for, and routing of, solutions to various social issues. As Kozel Jr. (1997, p. 214) reports, in that year, an article by Kotler and Zaltaman (1971) was also published in the Journal of Marketing. To define the idea of social marketing better, below are some statements on the subject: It is the institutional form of market action that has as the primary objective to mitigate or eliminate social problems: the needs of society particularly related to issues of hygiene and public health, labour, education, housing, transportation and nutrition.

Social marketing creates and manages the entire process whose actions and results are to build values that are added to products. The welfare, even if done systematically, adds to the concept of the company because it does not manage or have the authority and process control. (Kozel, 1997, p. 214)

Social marketing is one of the most promising developments, the actual implementation of which is expected to increase the effectiveness of social agents of change, in order to produce the desired social changes. Kotler (2007) posits that social marketing is a strategy to change behaviour. It combines the best elements of traditional approaches to social change in an integrated approach to planning and action and takes advantage of advances in communication technology and the capacity of marketing. Social marketing is the use of market planning, strategy analysis and the 
management of traditional and innovative techniques to ensure the welfare of individuals and society.

The strengthening of solidarity is the fundamental objective of social change, but this can be quite simple. People living in a given society have their ideas about life and personality, experiencing these within their social networks and events happening around them (Weilin \& Svetlana, 2012, pp.702-712). Thus, we suggest that the solidarity sector - non-profit organisations and foundations - is gaining vital importance in society. Therefore, the solution to social problems requires social change: changing how individuals and groups develop their lives, becoming productive despite adverse practices and changing attitudes and values in communities and societies.

Social responsibility in the long term can build a differential value for brands and competitive advantage for companies. Providing social changes that improve lives is a significant challenge for social campaigns and the primary purpose of the social marketing of organisations (Park, Philips \& Abbott, 2011, pp. 381-416). The social responsibility industry arises from a paradox between generosity, sociocultural rules and market. The offer of commercial social responsibility, according to Lashley (2008, pp. 69-84), ... "Depends on reciprocity based on monetary exchange and the guest satisfaction concession boundaries", which leads to impacts on the perception of the social responsibility of the guest/customer and the service provider. Reciprocity has its small features in this area (services) social responsibility since the context switching manifested in satisfaction with the services purchased.

The big difference between social marketing and social responsibility is that social marketing seeks to change the behaviour of society towards social well-being, using marketing tools and techniques, whereas corporate social responsibility is the concern shown by companies, people, and the government for social issues. Therefore, social marketing should be incorporated into companies' strategy in the current market environment, in which the process of globalisation is presenting more of a challenge to corporations, especially in their pursuit of productivity.

This can only be implemented in the social marketing of organizations when there is a change in the internal behaviour and values of company culture - based on ethical principles and social responsibility throughout production, administrative and commercial processes - which then will be reflected in the market as an external brand image through social marketing (Kotler, 2007).

\section{Research methodology}

The empirical data were collected from January to March 2014, and a second inductive process from March to July 2014 formed the basis of this study. The research method was based on grounded theory (Glaser \& Strauss, 1967), which is a form of qualitative research that seeks to generate new theories through concepts, categories and properties.
The emphasis of grounded theory is on learning from the data (i.e. inductive and interactive approach) and not from an existing theoretical view (i.e. deductive approach). The significant difference between grounded theory and other qualitative research methods is its specific focus on the development of theory through a continuous interdependence between data collection and analysis. It is an approach that provides a methodological framework often lacking in other qualitative approaches, without sacrificing flexibility or scientific rigour.

Grounded theory was developed within social science research, emphasising the inductive discovery of theory from systematically analysed data. Other authors have developed and discussed the method (Glaser \& Holton, 2007), reaffirming that (a) the main purpose of the method is the construction of theory, not only the coding and data analysis; (b) as a general rule, the researcher should not define a conceptual framework prior to the start of the study, to ensure that concepts can emerge without predefined conceptual biases and (c) analysis and conceptualization are obtained through the data collection process and constant comparison, in which each piece of data is compared with existing constructs - to enrich an existing category or establish a new form or new points of relationship between categories.

The field research was conducted in four small-sized companies located in the city of Três Corações. This qualitative study aimed to evaluate and identify the role that each company plays in the market in which it operates, considering aspects of social responsibility, social action, institutional marketing, social marketing and philanthropy. This study is characterised by exploratory descriptive market research (Mattar, 2005), which can be extremely variable when needed.

The sample size of this research is intentionally small since there was no clearly defined number of companies in this region, and the criteria used for obtaining the intended sample were companies that included programs within the research focus - social responsibility, social marketing, social action and their relationship with local tourism. The survey data were collected from March to June 2014.

Interviews were the data collection method, and, in their development, criteria such as the possibility of obtaining data directly from participants were considered. This meant the interviews could include open questions that allowed space for free-form answers with explanations and comments. In total, 176 questionnaires were filled out and assessed as being complete. These provided the survey data. About the formulation of the questionnaire, we considered the questions that drove this research and the goals and objectives presented above. The fundamental reason behind the choice of this method was the complexity of the problem under study. It required not merely measuring objects but discovering the nature of people's experiences concerning phenomena consistent with the social responsibility that must be present to 
support human lives, their values and their decisions. The questionnaires were given directly to employees, including shop floor personnel, office staff and management.

Companies seek to evolve in their management processes; therefore, it is necessary to work to improve all projected results. For these purposes, the favoured approach in this study, initially, was a review of the literature, to enable the establishment of a solid theoretical foundation and an understanding of the current status of quality management of work patterns. The literature search was performed using a database on physical and virtual entities in higher education, research centres, government agencies, professional bodies, databases and so on. Thus, using these descriptors, we obtained data that have been analysed in many qualitative researches. The findings were explained based on direct observation and description.

The subject, in general, is related to work, and it was probable that interviewees would seek assurances that, by taking part in the interviews, they would not be compromising their organisation. In this survey, all those who agreed to respond to questions were asked to consent to the use of their names and, as required by research ethics, were asked if all the data collected in the interviews could be presented in this paper. If the response was positive, we assured everyone that the content of this research was merely to be used for educational purposes and, therefore, was not intended in any way to denigrate the image of the organisations involved. What worked in favour of researchers is the fact that participants had an interest in their work and generally felt happy to have the opportunity to express their views, by whatever means available for communication. However, the trust needed to be guaranteed unconditionally in the initial approach.

In qualitative research, samples are generally smaller than those in quantitative researches are. Nonetheless, the data can be subtler and more complex. It became apparent, for example, that most of the interviewers' questions had to be open-ended to encourage full answers.

\subsection{Research on social responsibility and social marketing}

In order to discuss some findings of the overall situation regarding social responsibility and marketing and the companies' situation found in the research, we selected some important elements that proved to be correlated between the programs of the companies surveyed. The data presented are part of the field research conducted by the authors. The elements analysed in this article were drawn from four companies in the city of Três Corações. To collect the data, we used a self-administered questionnaire with a Likert scale that was administered individually to each employee in each company. The results expressed here refer to the answers to the questions given in the presence of the researchers (on 176 questionnaires with 21 Likert questions and 2 open questions) to achieve greater validity and reliability in the responses:
- General data on the contributors, of both sexes and with various functions in the operational, technical, supervisory and managerial areas, with 176 respondents

- The employees' perceptions of the companies concerning marketing and social responsibility

- The participation of employees in programmes to develop marketing and social responsibility and the context of the company

We sought to measure the satisfaction of employees concerning the management's programs relating to the programs related to social responsibility and marketing, connecting this to their values and the expected results for the companies. The data were collected using the SPSS 20.0 program on a Likert scale from 0 to 5 , where 0 meant totally dissatisfied and 5 completely satisfied. The main statements for each company were:

- The company has a social responsibility and social marketing programme.

- Initiatives in social responsibility and social marketing programmes in business are important.

- The employees appreciate the initiatives in social responsibility and social marketing programmes.

- You notice that the company handles social responsibility and social marketing programmes as part of their strategy.

- The social responsibility and social marketing programmes are tools for the company's strategic plan.

- The social responsibility and social marketing programmes may be factors that provide greater competitiveness for business, and they help strengthen local tourism.

- A qualitative research was, also, carried out with 276 residents of the city to know the perception that they have on the benefits from corporate social responsibility and corporate social marketing to strengthen the tourism.

\section{Analysis and results}

For the exploratory factor analysis, the variables of each of the constructs were subjected to a statistical technique that provided a comparison with the previously defined proposal and the results obtained from the field study. Regarding the perception of the marketing and social responsibility programmes' constructs within the companies' regular programmes, marketing and social responsibility were important, and employers valued the marketing and social responsibility programmes as tools in the strategic plans of their companies, allowing the researchers to keep the assessment factors obtained as previously defined, with no need for any adjustment.

From the results, it was possible to confirm the following aspects. The averages of the variables of interest in marketing and social responsibility can be considered intermediate, with 
high deviations. The highest averages were found in variables related to perception, participation and interest, which can be considered high at above 4 . Variables related to the business itself had lower averages.

Concerning differences, these can be considered intermediate as well. In general, the deviations can be considered intermediate to high, indicating a relatively high dispersion in the evaluation of employees. A more homogeneous aspect was the findings the strategic factor, with intermediate values for the averages and deviations, all with relatively close values between 3.449 and 4.071, and for the medium and standard deviations, between 0.763 and 0.976 in both areas. With these data, we conclude that, in general, employees with good work conditions considered the evaluation of marketing and the strategic aspect as extremely important for corporate social responsibility.
Using the Cronbach's alpha index, the variables were analysed for reliability in representing the constructs. The index was extracted for each construct, attaining acceptable values, all above 0.7 , (i.e. the reliability of the measures in the survey of the same object was estimated, being consistent within the data). With the results of the factor structure, the extracted index and reliability, we opted for the composition of variables to generate a general measure for each construct.

Taking, as a rule, the composition of the average scores of entries in the spreadsheet corresponding to each construct, the results for the alpha index values, the average and the standard deviation of each of the constructs are shown below. As can be seen in Table 1, the averages of the constructs have values between intermediate and high, and the standard deviations can be considered average.

Table 1 - Cronbach's alpha results for the means of the constructs

\begin{tabular}{|l|c|c|c|}
\hline \multicolumn{1}{|c|}{$\begin{array}{c}\text { CONSTRUCTS } \\
\text { (number of 21 elements) }\end{array}$} & $\begin{array}{c}\text { Cronbach's } \\
\text { Alpha }\end{array}$ & Average & $\begin{array}{c}\text { Standard } \\
\text { deviation }\end{array}$ \\
\hline Perception of marketing and social responsibility & 0.869 & 3.449 & 0.976 \\
\hline Marketing activities and social responsibility & 0.866 & 4.071 & 0.821 \\
\hline Value employees place on marketing and social responsibility & 0.689 & 3.683 & 0.763 \\
\hline Marketing activities and social responsibility as a strategy & 0.802 & 3.868 & 0.888 \\
\hline Marketing activities and social responsibility as a strategy tool & 0.833 & 3.859 & 0.913 \\
\hline Marketing activities and social responsibility as a competitive factor & 0.902 & 3.911 & 0.929 \\
\hline
\end{tabular}

Source: Research data.

The outcome for the means shows more clearly the placement of employees concerning the constructs referring to the development of practices to encourage marketing and social responsibility programmes, associated primarily with activities in the business world.

The cases defined for the study were evaluated using multiple regression analysis since this enabled the simultaneous assessment of the influence of the defined factors. Thus, the construct 'social marketing action and corporate social responsibility' was placed in a dependent condition, while in relation to the perception of marketing and social responsibility, the employees valued marketing and social responsibility (these are on the same scale as the dependent variable as seen in Table 1), and government regulations were inserted as an independent variable (see Table 2). The values of the regression model are estimated in Table 2 . The model could be considered consistent $\left(R^{2}=0.381\right)$ and, as is evident, only the constructs associated with 'social responsibility and marketing as a strategy' did not have a significant influence, as shown in the significance of the t-statistic for the standardised coefficients.

Table 2 - Results of multiple regressions

\begin{tabular}{|c|c|c|c|}
\hline CONSTRUCTS & $\begin{array}{c}\text { Standardised } \\
\text { coefficients }\end{array}$ & terros $\mathrm{t}$ & $\begin{array}{c}\text { Standard } \\
\text { errors }\end{array}$ \\
\hline Perception of marketing and social responsibility & 0.218 & 2.608 & 0.076 \\
\hline Marketing activities and social responsibility & 0.177 & 1.502 & 0.103 \\
\hline Value employees place on marketing and social responsibility & 0.222 & 3.970 & 0.024 \\
\hline Marketing activities and social responsibility as a strategy & 0.197 & 1.407 & 0.099 \\
\hline Marketing activities and social responsibility as a strategy tool & 0.188 & 2.007 & 0.108 \\
\hline Marketing activities and social responsibility as a competitive factor & 0.222 & 2.089 & 0.032 \\
\hline
\end{tabular}

The sum of the values corresponding strategies with marketing and social responsibility showed a positive average correlation, obtained based on the Pearson coefficient of 0.539 , significant at the 0.01 level, using the SPSS 20 program (Table 3 ). This indicates that of marketing and social responsibility have become one of the elements that must be present in the corporate business about strategy and incentives. 
Table 3 - Correlation: strategies - incentives

\begin{tabular}{|l|l|l|l|}
\hline & & Strategies & Incentives \\
\hline $\begin{array}{l}\text { Benefits } \\
1\end{array}$ & $\begin{array}{l}\text { Pearson Correlation } \\
\mathrm{N}\end{array}$ & 1 & $0.539^{* *}$ \\
\hline $\begin{array}{l}\text { Incentives } \\
2\end{array}$ & $\begin{array}{l}\text { Pearson Correlation } \\
\mathrm{N}\end{array}$ & $0.538^{* *}$ & 1 \\
\hline
\end{tabular}

Source: Research data.

** Correlation is significant at the 0.01 level (2-tailed).

Table 4 shows the correlation and determination of Pearson coefficient which indicates that $R$ squared of 0.290 and 0.289 for Strategies and Incentives have a moderate strength of relationship. The surveyed people related to the benefits and incentives to strengthen tourism and strategies carried out by the businesses used in this research for the application of the instruments. This allows an analysis of the importance of implementing a plan that promotes tourism in the city.

Table 4 - Determination of Pearson coefficient

\begin{tabular}{|c|c|c|c|c|}
\hline Model R & R squared & R squared adjusted & Standard error \\
\hline$(1) 0.539$ & 0.290 & 0.291 & 0.635 \\
\hline$(2) \quad 0.538$ & 0.289 & 0.290 & 0.635 \\
\hline
\end{tabular}

Source: Research data.

The results shown in Table 5 have a significance level of 0.01 according to the ANOVA test (Table 5). This allows us to consider the association of the strategies with marketing and social responsibility in the tourism companies in which the applied instrument resulted in the predictor value of 0.000 (constant).

Table 5 - Significance level based on the ANOVA test

\begin{tabular}{|c|c|c|c|c|c|c|}
\hline \multicolumn{2}{|r|}{ Model } & Sum of squares & gl & Quadratic mean & $\mathbf{F}$ & Sig. ${ }^{b}$ \\
\hline 1 & $\begin{array}{c}\text { Regression } \\
\text { Residue } \\
\text { Total }\end{array}$ & $\begin{array}{l}39.040 \\
53.841 \\
92.881\end{array}$ & $\begin{array}{r}1 \\
175 \\
176\end{array}$ & $\begin{array}{c}19.770 \\
0.288\end{array}$ & 42.130 & 0.000 \\
\hline 2 & $\begin{array}{c}\text { Regression } \\
\text { Residue } \\
\text { Total }\end{array}$ & $\begin{array}{l}43.225 \\
56.230 \\
99.455\end{array}$ & $\begin{array}{r}1 \\
175 \\
176\end{array}$ & $\begin{array}{c}20.821 \\
0.297\end{array}$ & 53.131 & 0.000 \\
\hline
\end{tabular}

Source: Research data.

With the results obtained and shown above, we concluded that the initiatives in marketing and corporate social responsibility within companies are an influential factor in the strategic performance of individuals and organisations. In order to ensure a more profound examination and exploration of the data, the measures of the constructs were evaluated concerning some of the most important variables that were included in the research. After the exploratory research had been conducted, field research was undertaken among residents of the city studied, resulting in a sample of 276 respondents to a questionnaire containing the following question: 'In your opinion, what kind of benefits from corporate social responsibility and corporate social marketing can strengthen tourism in the region?' The data showed that tourist activity is seen as positive and that the population considers tourism to be positive. In particular, $81.3 \%$ consider more income and rapid progress for the city with corporate social responsibility activities and social marketing, as Table 6 below demonstrates.

\section{Table 6 - Benefits of tourism activities}

\begin{tabular}{|l|c|c|}
\hline \multicolumn{1}{|c|}{$\begin{array}{c}\text { BENEFITS TO } \\
\text { STRENGTHEN TOURISM }\end{array}$} & QUANT & $\%$ \\
\hline More income & 85 & 48,3 \\
\hline Moderate income for the city & 43 & 24,4 \\
\hline Rapid progress for the city & 42 & 23,9 \\
\hline No benefits for the city & 6 & 3,4 \\
\hline Base & $\mathbf{1 7 6}$ & $\mathbf{1 0 0}$ \\
\hline
\end{tabular}

Source: Research data.

question 'In your opinion, is tourist activity positive for the city?' the data showed that the population considers tourism to be positive (see table 7). In particular, $88.1 \%$ consider the corporate social responsibility activities and social marketing firms undertake to strengthen tourism in the city of Três Corações to be great or good, when coupled with the encouragement of tourism development in the region. 
Table 7 - Incentive for tourism

\begin{tabular}{|l|c|c|}
\hline \multicolumn{1}{c}{$\begin{array}{c}\text { BENEFITS TO } \\
\text { STRENGTHEN TOURISM }\end{array}$} & QUANT & \% \\
\hline Great & 159 & 57,6 \\
\hline Good & 80 & 29,0 \\
\hline Regular & 28 & 10,1 \\
\hline Bad & 7 & 2,6 \\
\hline Very bad & 2 & 0,7 \\
\hline Base & $\mathbf{2 7 6}$ & $\mathbf{1 0 0}$ \\
\hline
\end{tabular}

Based on these results, the local population's perceptions were ascertained on issues related to the study regarding their knowledge of economic patterns (i.e. industry, commerce and tourism) in the region. The results indicate that companies, to achieve their goals and follow the requirements of legislation, should be increasingly concerned with the implementation of projects that are part of the strategic management of organisations. Marketing and social responsibility should be viewed as strategic elements of new companies to provide and achieve complete stakeholder satisfaction.

The quest for productivity and quality has been one of the main objectives of companies that want to survive in the current global environment marked by rapid and profound technological change. We live in a highly competitive society in which the quality of products and services offered have become a strategic differentiator. This differential solidifies the need for an integrated view of marketing, corporate social responsibility and management for continuous improvement.

\section{Conclusion}

This study provided evidence that concerns about marketing and social responsibility are increasingly present as a strategic factor in organisations. The results made it clear that marketing and social responsibility programs in the companies surveyed are taking shape and that employees and managers consider them to be essential tools for the economic and human capital development of their companies. This research is supported by findings in the economic sector reported by Tachizawa (2011) and Seade (2012).

This development, in short, can generate greater employee motivation by providing increased productivity, reduced costs and, therefore, significant gains in competitiveness. The surveyed companies, both medium-sized and large, have a satisfactory position in the markets they serve.

Regarding the perception of marketing and social responsibility as a strategic differentiator that creates more competitive businesses, $85 \%$ of the respondents agreed that this was true.

According to the data obtained on the perception of the importance of marketing and social responsibility in improving the performance of the organisations studied, it is fundamental to use models that conceptualise these initiatives as a business strategy.
The respondents also agreed that social responsibility and social marketing programs developed by companies encourage the growth of tourism (88.2\%) and benefits to the city (88.8\%), as a result of tourist activities involving social responsibility and social marketing.

Social responsibility and social marketing are not merely strategic supporting programmes. Ethical behaviour and transparency in dealing with all matters involving companies and directly or indirectly influencing surrounding communities - and society in general - also contribute to the formation of corporate citizens, which is an essential management philosophy. These can then help strengthen tourism in the region. Social marketing campaigns can provide credibility to companies' names with their market and consumers, especially when campaigns are based on consistent corporate social responsibility programmes. Polarisers are positives that arise after the programmes are implemented, and they can strengthen the desire to visit the tourist region studied.

This study sought to contribute to the advancement of knowledge in corporate marketing and social responsibility, thus taking one more step along the path of contributing to future research on these subjects. For this reason, this research is expected to stimulate new research and debates that involve marketing and social responsibility initiatives and strengthening tourism, which significantly supports socioeconomic development in the face of increasingly complex markets.

\section{Limitations and opportunities for future research}

The first limitation of this study is the inability to make generalisations for all companies and all business sectors within an expanded geographic scope, as well as for other industries. Therefore, the replication of this study is suggested for other economic contexts, whether involving products or services or the same sector, but analysed in different geographic regions. Additional research models are also suggested for future research, to compare to the one proposed in this study in order to move the theoretical model closer to reality.

Future studies should deepen this analysis to elucidate further the question of strategy-based marketing and social responsibility programmes, as well as the affective commitment of people within companies. This is to check whether the method of evaluating this commitment should not be changed, to adopt initiatives to the region better and 
encourage greater involvement of people within the business and achieve higher business performance.

It is recommended for future research that companies' decisions participate in the development of social projects be seen not only as the work of the top management of organisations but also as a task shared by all members of organisations. Another recommendation for future studies is to measure the viability of the financial investment of organisations, which could be deemed to provide consistent criteria by which to measure the pay-off for social projects, involving, preferentially, municipal programmes of tourism development in each region.

More long-term research should be undertaken to ascertain whether organisations are using proper decision-making tools for reaching goals in social areas. Finally, studies should be developed to help design management models, to enable companies to analyse the results obtained from social marketing and corporate social responsibility.

\section{References}

Barakat, S. R. \& Polo, E. F. (2016). Implicações estratégicas da responsabilidade social corporativa. Revista de Gestão Social e Ambiental, 10(2), 37-52.

Bronn P. S. \& Vrioni, A. B. (2001). The handbook of communication and corporate reputation corporate social responsibility and cause-related marketing: an overview. International Journal of Advertising, 20(2), 207-222.

Burriel, O. A. (2015). Corporate social responsibility, income distribution and the environment: an empirical study for the European union. In Agata Stachowicz-Stanusch (Ed.), Corporate social responsibility: income, distribution and the environment, in corporate social performance in the age of irresponsibility. Cross-national perspective (pp. p.65-74), Charlotte, NC: Information Age Publishing.

Carroll, A. B. \& Schwartz, M. (2003). Corporate social responsibility: a three-domain approach. Business Ethics Quarterly, 13(4), 503-530.

Carroll, A.B. \& Buchholtz A. (2014). Business and society: ethics, sustainability, and stakeholder management. Stanford: Cengage Learning.

Carroll, A.B. (1999). Corporate social responsibility: evolution of a definitional construct. Business and Society, 38(3), 268-295.

Chatjuthamard, P., Jiraporn, P., Tong, S. \& Singh, M. (2015). Managerial talent and corporate social responsibility: how do talented managers view corporate social responsibility? International Review of Finance 16(2), 265-276.

Chintrakarn, P., Jiraporn, P., Kim, J.C. \& Kim, Y.S. (2016). The effect of corporate governance on corporate social responsibility. Asia-Pacific Journal of Financial Studies, 45(1), 102-123.

Coleman, J. S. (2000). Social capital in the creation of human capital. American Journal of Sociology, 94, 95-120.

Cox, C., Burgess, S., Sellito, C. \& Buultjens, J. (2009). The role of usergenerated content in tourist' travel planning behavior. Journal of Social Responsability Marketing \& Management, 18(8), 743-764.

Craig, E. C. (2015). The handbook of communication and corporate reputation. New Jersey: Willey \& Sons.

Drucker, P. (1992). Administrando para o futuro: os anos 90 e a virada do século. São Paulo: Pioneira.

Enderle, G. \& Tavis, A.L. (1998). A balanced concept of the firm and the measurement of its long-term planning and performance. Journal of Business Ethics, 17(11), 1129-1143.
ETHOS - Instituto Ethos de Responsabilidade Social. (2011). Matriz de evidências de sustentabilidade, banco de práticas e ferramentas de gestão: indicadores ethos, guia de elaboração de balanço social. Retrieved 14 December 2017 from www.ethos.org.br

Flammer, C. (2013) Corporate social responsibility and shareholder reaction: The environmental awareness of investors. Academy Management Journal, 56(3), 758- 781.

Flammer, C. \& Luo, J. (2016). Corporate social responsibility as an employee governance tool: evidence from a quase-experiment. Strategic Management Journal, 37(3), 447-465.

Gaioto, F. R. (2001). Da responsabilidade social à ética empresarial aplicada ao relacionamento com clientes em processos pós-vendas: estudo de caso. Masters dissertation, Federal University of Santa Catarina, Brazil.

Garcia, I, Gibaja, J.J. \& Mujika, A. (2013). User innovation in Gipuzkoa. A descriptive approach. Cuadernos de Administración, 26(46), 61-81.

Garcia, I, Gibaja, J.J. \& Mujika, A. (2001). Marketing social corporativo - la respuesta a una demanda social. Estudios Empresariales, 105(1), 26-32.

Glaser, B. \& Strauss, A. (1967). The Discovery of Grounded Theory. Chicago: Aldine.

Glaser, B. \& Holton, J. (2004). Remodeling grounded theory. The Grounded Theory Review, 4(1), retrieved 15 August 2017 from http://groundedtheoryreview.com/2004/11/30/1612/

Henderson, H. (2006). Ethical market: growing the green economy. Waren: Ethical Market Institute.

Hiller, J. S. (2013). The benefit corporation and corporate social responsibility. Journal of Business Ethics, 118(2), 287-301.

Loannou I, Serafeim G. (2014). The impact of corporate social responsibility on investment recommendations. Journal of Business Ethics, 119(1) 77-86.

King, R. K. \& Schwartz, R. (2000). An experimental investigation of auditors' liability: implications for social welfare and exploration of deviations from theoretical predictions. The Accounting Review, 75(4), 429-451

Kotler, P. (2007). Marketing. São Paulo: Atlas.

Kotler, P. (2008). Marketing social, São Paulo: Atlas.

Kotler, P. \& Zaltman, G. (1971). Social marketing an approach to planned social change. Journal of Marketing, 35(1), 3-12.

Kozel Júnior, J. (1997). O top do marketing brasileiro. São Paulo: Scipione.

Lashley, C. (2008) Studying Social responsibility: Insights from Social Sciences. Scandinavian Journal of Social responsibility and Tourism, 8(1) 69-84.

Leisinger, K. M. (2015). Corporate responsibility in a world of cultural diversity and pluralism of values. Journal of International Business Ethics, 8(2), 9-36

Llena, F. M. (2007). La incorporación de la responsabilidad social corporativa en la gestión estratégica através del balanced scorecard: Relación con las memorias de sostenibilidad. XIII Congreso AECA Armonización y Gobierno de la Diversidad, Oviedo, Spain.

Lyons K, Hanley J, Wearing S, \& Neil, J. (2012) Gap year volunteer tourism: myths of global citizenship? Annals of Tourism Research 39, 361-378.

Mattar, F.N. (2005). Pesquisa de marketing. São Paulo: Atlas.

Micchelli J. (2012) Value chain approaches to assessing the impact of tourism on low-income households in developing countries. Journal of Sustainable Tourism, 20(3), 457-475.

Park, K., Philips, W. J., Canter, D. D., \& Abbott, J. (2011) Social responsibility and tourism research rankings by author, university, and country using six major journals: The first decade of the new millennium. Journal of Social responsibility and Tourism Research, 35(3), 381-416.

Racherla P., Hu, C. (2010) A social network perspective of tourism 
research collaboration. Annals of Tourism Research, 37(4), 1012-1034. Richers, R. (2001). Marketing, uma visão brasileira. São Paulo: Nobel.

SEADE. (2012). Índice paulista de responsabilidade social. Retrieved 31 March 2016 from http://www.seade.gov.br.

Seidel, M-D., S, Whitehead, L., Mossman, M. A. \& Sá, C. (2017). The distributed network of cooperating teams (DNCT): a multi-level initiative for organizational change. Vancouver: University of British Columbia.

Srour, R. H. (2005). Poder, cultura e ética nas organizações: o desafio das formas de gestão. Rio de Janeiro: Campus.

Strauss, A. \& Corbin, J. (1997). Grounded theory in practice. London: Sage Publications.

Schwartz, M. S. (2011). Corporate social responsibility: an ethical approach. New York: Broadview Press.

Tachizawa, T. (2011). Gestão ambiental e responsabilidade social corporativa. 6. São Paulo: Atlas.

UND United Nations Development (2007). Human Development Report 2007/2008. Fighting climate change, human solidarity in a divided world. UNDP, New York. Retrieved 22 April 2016 from http://www.pnud.org.br/arquivos/rdh/rdh20072008/hdr20072008pt. complete.pdf

Watson, J. D. (1972). Origin of concatemeric T7 DNA. Nat New Biology, 239(94), 197-201.

Weilin, L. \& Svetlana, S. (2012). Ecotourism experiences reported online: Classification of satisfaction attributes. Tourism Management, 33(3), 702-712.

Zenone, L. C. (2007). Marketing Social. São Paulo: Thomson.

Wu, M. \& Adams, R. (2007). Applying the Rasch model to psycho-social measurement: A practical approach. Melbourne: Educational Measurement Solutions.

Received: 15 January 2018

Revisions required: 23 July 2018

Approved: 12 October 2018 